\title{
Hukum Islam di Kemudian Hari
}

\author{
Oleh: \\ Muhyidin \\ Fakultas Hukum Universitas Diponegoro \\ muhydin85@yahoo.com
}

\begin{abstract}
Abstrak:
Hukum di Indonesia sebagai akibat dari perkembangan sejarah, bersifat majemuk. Disebut demikian karena sampai sekarang dalam Negara Republik Indonesia berlaku beberapa sistem hukum yang mempunyai corak dan sistem sendiri. Yang dimaksud adalah sistem hukum Adat, sistem hukum Islam, sistem hukum Barat. Berlakunya hukum Islam untuk orang Islam Indonesia tidak disandarkan pada hukum Adat atau hukum lainnya, tetapi pada penunjukan peraturan perundangan sendiri. Mengenai keberadaan hukum Islam dalam sistem hukum di Indonesia adalah sejajar dengan hukum Adat dan hukum Barat, karena itu hukum Islam dapat menjadi sumber bagi pembentukan hukum nasional yang akan datang.
\end{abstract}

Kata-kata kunci: hukum Islam, sumber hukum nasional, instrumen hukum. 


\section{A. PENDAHULUAN}

Seorang sarjana hukum dan politikus Romawi yang masih hidup pada masa abad kedua sebelum masehi berkata: "Ubi sociates ibi ius" (Anwar Haryono, 1968:18) di mana ada masyarakat, di sana ada hukum.

Pendapat ini tidaklah selamanya benar, karena hukum tidaklah mengatur hubungan antar manusia saja, tetapi hukum mengatur juga terhadap alam jagad raya ini, lebih-lebih lagi apabila masyarakat hidup di bawah payung Pancasila di kala hidup di kesunyian dan kesendirian pun di situ ada hukum.

Berbicara mengenai hukum Islam di negara Republik Indonesia yang berdasarkan Pancasila ini, tidak boleh tidak kita akan dihadapkan pada masalah politik, dalam hal ini masalah politik hukum. Politik hukumlah sebagai faktor dominan yang menentukan berlakunya hukum dalam suatu negara, tanpa adanya politik hukum, sesungguhnya hukum itu tak akan ditaati oleh warga masyarakat.

Di samping politik hukum yang berpengaruh dengan frekuensi yang berbeda pada masing-masing negara sesuai dengan kebutuhan situasi dan kondisi negara yang bersangkutan ialah faktor kesadaran hukum, dan faktor rasa keadilan.

Politik hukum suatu negara dapat dilihat atau dijumpai dalam konstitusi negara yang bersangkutan, untuk negara Republik Indonesia hal itu dapat dilihat atau dijumpai di dalam UUD 1945. UUD 1945 itu sendiri terdiri dari "pembukaan”, yang terdiri atas empat alinea, "batang tubuh" yang terbagi atas 16 bab dengan 37 pasal ditambah pasal aturan peralihan dan 2 ayat aturan tambahan, serta penjelasannya. Ketiganya adalah merupakan kesatuan yang utuh, yang satu sama lainnya tidak dapat dipisahkan. Apa yang dimuat dalam pembukaan dimanifestasikan dalam batang tubuhnya dalam bentuk bab-bab, pasal-pasal dan seterusnya dijelaskan lebih lanjut dalam penjelasannya.

Sehubungan dengan masalah tersebut, bagi masyarakat kita yang berfalsafah Pancasila dalam membentuk dan melaksanakan hukum yang berlaku di negara ini seyogyanya hukum yang dilaksanakan itu bukan hukum sekuler, yang hanya merupakan satu segi dan penjelmaan hidup kemasyarakatan saja, tetapi hukum yang berlaku itu adalah hukum-hukum yang mempunyai dimensi Ketuhanan, sesuai dengan sila pertama Pancasila "Ketuhanan Yang Maha Esa".

Dalam pembukaan Undang-Undang Dasar 1945 disebutkan "Atas berkat rahmat Allah..........." , begitu pula dalam pasal 29 Undang-Undang Dasar 1945 menyebutkan:

(1) Negara berdasarkan atas Ketuhanan Yang Maha Esa.

(2) Negara menjamin kemerdekaan tiap-tiap penduduk untuk memeluk agamanya masing-masing dan untuk beribadah menurut agamanya dan kepercayaannya itu.

Dengan demikian salah satu dasar negara Republik Indonesia adalah Ketuhanan Yang Maha Esa, yang dalam pembukaan telah disebutkan, oleh batang tubuh diulangi lagi dengan tanpa tedeng aling-aling: "Negara berdasarkan atas Ketuhanan Yang Maha Esa". Jadi jelaslah bahwa sila Ketuhanan Yang Maha Esa adalah garis hukum yang harus dipatuhi dan dijunjung tinggi dalam negara kita (Ismail Suny, 1981:86). 
Guna memperoleh gambaran yang jelas, walaupun tidak panjang lebar dan mendalam makalah ini akan dititikberatkan pada: Hukum Islam sebagai sistem hukum, tempat dan kedudukan hukum Islam di negara Republik Indonesia, dan prospek hukum Islam di masa mendatang.

\section{B. HUKUM ISLAM SEBAGAI SISTEM HUKUM}

Di negara Indonesia ini berlaku beberapa sistem hukum. Dan segi umurnya, yang tertua adalah hukum adat, kemudian hukum islam dan kemudian hukum barat. Ketiganya mempunyai ciri dan sistem tersendiri, tumbuh dan berkembang dalam masyarakat dan negeri Republik Indonesia karena itu sistem hukum di Indonesia disebut majemuk (Muhammad Daud Ali, 1984:6).

Indonesia merupakan suatu contoh yang menarik sekali karena sistem hukum yang berlaku di dalamnya, merupakan salah satu paling komplek di seluruh dunia dan nampaknya tidak lain disebabkan keadaan sosial dan politik bahkan di setiap segi dan bidang akan nampak Indonesia adalah serba kompleks (Daniel S. Lev, 1986:19).

Hukum Islam adalah ansich artinya hukum Islam tersebut meliputi segala macam pengertian hukum, yaitu hukum privat (al-qununal khas), dan hukum umum (alkununal aam). Hukum privat Islam meliputi hukum dagang (at-tijaroh) dan hukum acara (almurafat) dan hukum privat internasional (ad-dauliyulkhas), yang termasuk hukum umum/publik ialah hukum pidana (al-jinai), hukum ketatanegaraan, administrasi dan keuangan (as-siyatus-syar'ah ad-dusturi, al-idari dan al-mali), dan hukum intemasional (al-fighuddauli).

Kalau kita meninjau tata aturan pada hukum sekuler maka tujuannya tidak lain sekedar ketentraman masyarakat yaitu dengan jalan mengatur sebaik-baiknya dan menentukan batas-batas hak dan kewajiban dalam hubungan satu sama lain. Tujuan yang bernilai tinggi dan abadi tidak menjadi perhatian. Bila kita bandingkan dengan hukum Islam, maka tujuan hukum Islam lebih tinggi dan bersifat abadi, artinya tidak terbatas pada lapangan materiil yang bersifat sementara, karena faktor-faktor individu, masyarakat, dan kemanusiaan pada umumnya selalu diperhatikan dan dirangkaikan satu sama lain, dan dengan hukum Islam dimaksudkan agar kebaikan mereka semua dapat terwujud.

Dalam lapangan ibadah misalnya sholat, puasa, zakat, dan sebagainya dimaksudkan untuk membersihkan jiwa dan mempertemukan dengan Tuhan, kesehatan jasmani dan kebaikan individu maupun masyarakat dengan berbagai-bagai seginya.

Di lapangan muamalah (hubungan sesama manusia) dengan segala macam tujuan dapat kita lihat pada aturan pokok dalam hukum Islam ialah sebagai berikut:

1. Menolak bahaya/kerusakan didahulukan atas menarik kemaslahatan.

2. Keadaan yang darurat, memperbolehkan hal-hal yang terlarang.

3. Hukum itu tergantung illatnya.

4. Hukum itu berubah, mengikuti perubahan zaman. 
Keberadaan hukum Islam artinya hukum yang berasal dari Agama Islam. Adanya hukum Islam tidak dapat dipisahkan dengan eksistensi Agama Islam itu sendiri (Ahmad Hanafi, 1970:18).

Hukum Islam bersumber dan Al-Qur'an dan Al Hadist atau juga disebut Assunah. Setiap orang yang berkecimpung dalam lapangan hukum Islam harus terikat dengan teks-teks kedua sumber hukum tersebut. Kalau tidak ada ketentuan yang jelas dalam kedua teks tersebut secara langsung, maka harus terikat dengan jiwa syari'at dan dasar-dasar yang umum (Hashbi Ashidqi, 1975:17).

Dalam keadaan demikian timbullah lapangan ijtihad yang luas dari berbagai aliran dalam hukum Islam. Dengan demikian sumber hukum Islam adalah wahyu Tuhan.

Keadaan ini berbeda sama sekali dengan hukum yang sekuler, karena hukum yang terakhir ini adalah buatan manusia. Hobbes mengatakan, bahwa undang-undang bukan saja aturan tetapi merupakan perintah dan orang yang berkuasa yang harus dipatuhi (Ibid, 19). Pendapat tersebut kemudian diikuti oleh Austin yang menyatakan bahwa undang-undang timbul dari kehendak para penguasa dalam masyarakat, baik merupakan perseorangan maupun badan tertentu, sesudah itu semua harus tunduk kepada kehendak itu. Kemudian sesudah kumpulan kitab undang-undang dan Napoleon (kodifikasi Napoleon) timbullah suatu aliran di Prancis yang menyatakan bahwa kumpulan undangundang tersebut sudah memuat segala yang diperlukan. Kalau kita mengadakan perbandingan-perbandingan antara aliran-aliran hukum pada hukum sekuler tersebut maka akan nampak persamaan dengan hukum Islam, baik klasifikaslnya maupun sistemnya, meskipun terdapat segi-segi persamaan, juga terdapat segi-segi perbedaan, yang menonjol antara lain:

1. Kehendak Tuhan tidak bisa disamakan dengan kehendak manusia yang selalu mengalami kekurangan, sesuai dengan sifatnya. Oleh karena itu undang-undang yang diciptakan manusia tidak dapat selamanya membawa kebahagiaan.

2. Teks-teks (nas-nas) dari Qur'an dan Hadits terjamin dari kesalahan, sedangkan hukum buatan manusia bagaimanapun keadaannya tidak terlepas dari kesalahan dan kekurangan.

3. Hukum Islam memperoleh penghormatan yang tinggi dan suci. Hal ini disebabkan hukum Islam bersumber pada wahyu Tuhan. Oleh karena itu hukum Islam bisa mengalami kesetabilan.

Menyinggung sistem hukum Islam, kiranya patut direnungkan sejenak apa yang diutarakan oleh Mukti Ali ketika masih menjabat Menteri Agama:

Hukum Islam tidak pernah menampakkan wajahnya "wajar dan sempuma" (dalam anti bulat dan utuh sebagai sistem hukum), karena pada umumnya orang hanya membahas pernikahan di samping bidang ibadah sedang bidang lain kurang mendapat perhatian. (Suryoyo Wignyodipuro IMajalah Haluan. 247. 1973:4-7). 
Apa yang dikemukakan oleh Mukti Ali tersebut adalah suatu pernyataan yang tidak dapat dipungkini, oleh karena hukum Islam yang dianggap sebagai hukum positif hanyalah sejumput kecil dari hukum Islam. Sejumput kecil itu adalah hukum Islam yang dalam lapangan hukum pedata. yaitu yang menyangkut sebagian dari hukum perkawinan, nikah, talak, cerai, dan rujuk.

Di pandang dari sudut materi hukumnya berdasarkan tinjauan hukum positif, tidak dijumpai suatu peraturan perundang-undangan Indonesia yang mengatur hal ini Perundang-undangan yang ada hanyalah berfungsi atau merupakan apa yang dikenal dengan "hukum (kaedah) penunjuk" (verwij = ingsregels). Itu berarti ia tidak mengatur materi (yang bersumber) hukum Islam itu sendiri sebagai isinya, melainkan menunjuk kepada aturan lainnya.

Keadaan seperti apa yang digambarkan di atas adalah sebagai akibat dari politik hukum (dan politik Islam) yang berasal dari zaman penjajahan dulu. Seperti diketahui dalam rangka melanggengkan kekuasaan penjajahan di Indonesia, pemerintah kolonial berusaha demikian rupa sehingga Islam sebagai agama mayoritas bangsa Indonesia semakin diabaikan, yang tujuannya adalah divide et impera yang berakhir dengan "deislamisasi" umat Islam di Indonesia.

Dengan demikian hukum Islam dengan sendirinya tidak lagi mengatur dan menguasai tingkah laku para penganutnya. Akibatnya lebih jauh ialah hukum Islam tidak akan diangkat atau terangkat menjadi hukum positif atau dengan perkataan lain hukum Islam itu dapat di kesampingkan.

Agar tidak terlalu mengejutkan umat Islam di satu pihak dan di pihak lain seolaholah hukum Islam itu masih diberi tempat dan dipertahankan berlakunya, kita mengenal suatu teori resepsi atau receptio theory yaitu merupakan teori yang menyatakan, bahwa hukum Islam berlaku sebagai hukum manakala telah diresepsi hukum adat.

Pendukung teori ini antara lain sarjana-sarjana Belanda yang terkenal (Suryoyo Wignyodipuro, 1973:22):

1. Prof Snouck Hogronye.

2. Mr. Van Ossenbrugen dalam bukunya "Oorsprongen Eerste Ontwikkeling van her Tester en Voogedijrecht".

3. Mr. CC. Van Vollenhoven dalam bukunya "hat Adat Rech van Nederland Indie"

4. Mr. I. A. Piepers dalam majalah "Tijdschif van Nederland indie".

5. Mr. Naderburgh dalam bukunya "Wet en Adat".

Untuk melegitimasi pendapat ilmiawan tersebut diungkapkan pasal 134 (2) Wet op de Staatsinrichtini van Nederland Indie, yang berbunyi:

"Even wet staan de burgerlijge rechtzaken tusschan Mohamadenen, indien hun adatrecht dat madeprengt, terkenisneming van den godsientigen retchter, vor zoorver niet hij ordonantie andres is bepaald" Jelasnya apabila terjadi perkara yang diselesaikan oleh hakim agama Islam. jika telah diterima oleh hukum adat mereka, sejauh tidak ditemukan lain oleh ordonansi (Soepomo, 1952:30). 
Keadaan seperti demikian itulah yang berlaku sampai sekarang ini. Demikianlah sumber formal bagi hakim untuk menyelesaikan perkara perdata antara sesama orang Islam, diselesaikan berdasarkan hukum adat.

Tegaknya hukum Islam baru akan berlaku kalau hukum adat daerah setempat menghendaki hukum Islam itu diperlukan, kalau tidak maka hukum adatlah yang berlaku. Hukum Islam hanya sebagai penumpang dalam kendaraan yang bernama hukum adat. Oleh karena itulah tidak mengherankan apabila Hazairin (almarhum) seorang yang ahli dalam bidang hukum adat dan hukum Islam mengatakan:

Teori resepsi telah diciptakan kekuasaan kolonial Belanda untuk merintangi kemajuan Islam di Indonesia adalah teori iblis karena mengajak orang Islam untuk tidak mematuhi dan melaksanakan perintah Allah dan sunah rosulnya. Menurut teori resepsi hukum Islam bukanlah hukum kalau hukum Islam itu belum diterima dan menjadi hukum adat (Hazairin, 1964:4)

Oleh karena berlakunya hukum Islam itu dinunutkan pada hukum adat, maka timbullah kelainan-kelainan di dalam pelaksanaan hukum Islam di berbagai daerah. Buktinya dapat dilihat pada perkembangan dan pertumbuhan serta luasnya tugas dan kekuasaan dan peradilan agama yang berbeda dan beraneka ragam coraknya sehingga diatur secara seporadis.

Ordonansi peradilan agama diatur dengan keanekaragaman itu misalnya:

1. S. 1882-152, 153 diubah dengan S. 1937-116 terakhir dengan S. 1940-3;

2. S. 1937-638;

3. Verordening CCO AMACAB untuk Jawa Madura 8 November 1946 (Jay. 1946 no. 32, 39);

4. Putusan RECOMBA Jawa Barat 26 Pebruari 1948:

5. Ketetapan Wali Madura 21 Juni 1948;

6. Ketetapan Wali Negara Sumatra Timur 1 Agustus 1950 no. 359/1950 (warta resmi NST 70/1950) (Sudikno Martokusumo, 1984:63).

Peraturan yang sebanyak itu, dapatlah menimbulkan kesan betapa semrawutnya Pengadilan Agama itu, dan akhirnya timbul kesan kurang mutu.

Bahwa sampai saat ini masih ada pihak-pihak yang menganut atau mengikuti ajaran teori iblis itu adalah wajar, terutama disebabkan sistem pendidikan hukum yang diwarisi dan penjajah Belanda dulu.

Yang menjadi persoalan adalah, apakah memang benar bahwa hukum Islam itu baru berlaku atau baru akan diterima oleh masyarakat Indonesia kalau ia diterima (diresepsi) oleh hukum adat indonesia? Tidakkah hukum Islam ansich yang merupakan isi materi hukum adat. Oleh karena telah sedemikian lamanya sudah mendarah daging dalam masyarakat Islam Indonesia yang katanya mayoritas itu? Lebih dari itu apakah benar bahwa berlakunya hukum Islam itu dimana dan kapanpun harus dengan perantaraan hukum lain-nya? Yang bagaimanapun juga adalah ciptaan manusia mahluk Tuhan, kalau demikian halnya hukum apakah yang berlaku dan menguasai tingkah laku 
masyarakat dan kerajaan Islam: Demak, Pajang, Mataram, Samudra Pasai, Banten, Kerajaan Islam Riau, Kasultanan Aceh, Kesultanan Palembang, Kerajaan-kerajaan Islam di Sulawesi Selatan, Kesultanan Tidore dan Ternate, Kerajaan Minangkabau dengan pepatah yang terkenal "Adat bersendikan Syarak, Syarak bersendikan kitabullah dan lain sebagainya”. Hukum adatkah ataukah hukum Islam? Mengapa orang kita dahulu, malahan juga masih hidup sampai sekarang tidak buta terhadap huruf Arab yang juga adalah huruf Al-Qur'an, dan oleh karena itu kemungkinan besar juga tidak akan buta terhadap hukum dan ajaran Islam. Bukankah kita semenjak mengucapkan dua kalimah syahadat telah berjanji berdasarkan keimanan dan kecintaan telah memilih agama Islam dengan segala atribut-atributnya, termasuk di dalamnya adalah hukum.

Maka tepatlah apa yang dikemukakan oleh Ismail Suny:

........berdasarkan kenyataan bahwa pengaruh yang amat besar terhadap kehidupan

Bangsa Indonesia adalah pengaruh agama Islam yang hingga sekarang masih tetap berlangsung, karena sebagian Bangsa Indonesia menganut agama Islam, maka sebelum kedatangan Belanda, untuk sebagian besar kepulauan Indonesia hukum Islam pernah merupakan hukum satu-satunya (Suny, 338).

Jawaban terhadap pertanyaan di atas sesungguhnya menghendaki penelitian yang mendalam, tuntas dan menyeluruh, tetapi yang jelas di sini dapat dikemukakan bahwa banyak lembaga tatanan ke-Islaman sampai saat ini masih hidup di dalam kalbu masyarakat Indonesia. Yang boleh dikatakan merupakan ciri kepribadian dan bentuk ketatanegaraan Indonesia asli yang bercorak Islam. Bagaimanapun ditekan hendak dilenyapkan oleh Balanda ia tetap menampakkan eksistensinya.

Dengan segala kelebihan dan kekurangannya maka pada hakekatnya adanya jabatan "Sulthan", "Kanjeng Penghulu", "Hakim", sampai dengan Labai, Modin, dan lain sebagainya.

Begitupun struktur pemerintahan negeri/kampung/desa sesungguhnya merupakan penjelmaan dari watak ketatanegaran (staatkundingkrahter) dari pelaksanaan syari'at Islam. Lihat juga bangunan masjid di Jawa dan Madura yang terletak di sebelah barat alun-alun dan berseberangan dengan Istana atau Kabupaten.

Pemerintah penjajah sendiri nyatanya juga berusaha membuat himpunan hukum Islam, antara lain: (1). Pepakem Cirebon (dalihnya hukum adat), (2). Compedium Friyer (1760) suatu himpunan peraturan hukum Islam mengenai warisan, nikah, talak, Compedium ini secara berangsur-angsur dicabut, yang terakhir mengenai warisan pada tahun 1913 dengan LNHB 1913 no. 354, (3). Kitab Hukum Mogherer (1750) untuk kepulauan Landrad Semarang, yang memuat hukum Pidana Islam, (4). Compedium Bone dan Gowa (1605) di mana Islam telah resmi menjadi agama negara di seluruh kerajaan di Sulawesi Selatan.

Gambaran terhadap hukum Islam seperti tersebut di atas tidak mencerminkan sistem hukum Islam dalam arti yang benar. Kiranya di sini tidak perlu lagi ditegaskan hukum Islam telah sedemikian dipersempit ruang geraknya dengan berbagai dalih dan berbagai alasan. Ruang sempit bergeraknya hukum Islam agaknya sampai saat ini masih dirasakan, itulah juga suatu kenyataan dan itulah pula "karya besar" dari para ilmuan, 
semisal Snouck Hogronye, Van Voollenhoven, Terhaar, dan kawan-kawanya, yang ingin memisahkan kecintaan kita kepada Allah dan Rasul.

\section{TEMPAT DAN KEDUDUKAN HUKUM ISLAM}

Bagaimanakah dan di manakah tempat hukum Islam dalam negara Republik Indonesia, harus dilihat seperti dikatakan pada permulaan makalah ini, bahwa hukum Islam artinya hukum yang berasal dari agama Islam. Adanya hukum Islam sendiri tak dapat dipisahkan dengan eksistensi agama Islam. Dengan sendirinya pula bagaimana negara Republik Indonesia ini memandang dan memberi arti keberadaan agama Islam itu sendiri. Sekalipun negeri Republik Indonesia yang berdasarkan Pancasila dan oleh karena itu dapat pula disebut negara Pancasila bukan negara "agama", apalagi negara yang berdasarkan Islam. Tetapi yang jelas bukan negara yang "sekuler", karena negara Republik Indonesia ini memandang dan menempatkan agama pada umumnya, agama (hukum) Islam khususnya secara tersendiri.

Pada alinea keempat Pembukaan Undang-Undang Dasar 1945 dinyatakan dengan jelas dan tegas bahwa Negara Republik Indonesia berkedaulatan rakyat, dengan berdasarkan kepada: Ketuhanan Yang Maha Esa, Kemanusiaan yang adil dan beradab, Persatuan Indonesia dan Kerakyatan yang dipimpin oleh kebijaksanaan dalam permusyawaratan/perwakilan, serta dengan mewujudkan suatu keadilan sosial bagi seluruh rakyat Indonesia.

Mengenai dasar negara ini terdapat penegasan lebih lanjut dalam Batang Tubuhnya yaitu dalam pasal 29 ayat 1 yang berbunyi: Negara berdasarkan Ketuhanan Yang Maha Esa. Selanjutnya di dalam penjelasan bagian umum dijumpai rumusan: Pokok pikiran yang keempat yang terkandung dalam pembukaan ialah negara berdasarkan Ketuhanan Yang Maha Esa menurut kemanusiaan yang adil dan beradab, dari ayat ini menyatakan kepercayaan Bangsa Indonesia terhadap Tuhan Yang Maha Esa.

Di samping itu harus diingat pula bahwa Dekrit Presiden 5 Juli 1959 dinyatakan dengan tegas lagi tandas bahwa Piagam Jakarta adalah menjiwai UUD 1945 dan merupakan rangkaian kesatuan dengannya (Ibid:339). sungguhnya Piagam Jakarta dan Pembukaan UUD 1945 tidak dapat dipisahkan.

\section{PROSPEK HUKUM ISLAM MASA MENDATANG}

Sesungguhnya usaha-usaha untuk mengembalikan dan menempatkan hukum Islam dalam kedudukannya seperti semula (seperti sebelum tahun 1929) terus dilakukan oleh para pemimpin Islam. Ketika Badan Penyelidik Usaha Persiapan Kemerdekaan terbentuk dan bersidang untuk merumuskan dasar negara dan menentukan hukum dasar bagi negara Indonesia merdeka di kemudian hari. para pemimpin Islam yang menjadi anggota badan tersebut terus berjuang dan berusaha untuk mendudukkan Islam dalam negara Republik Indonesia itu kelak, yang terkenal dengan sebutan "Piagam Jakarta" (22 Juni 1945). Di dalam Piagam Jakarta tersebut terdapat rumusan yang kemudian ditenima oleh BPUPKI sebagai Pembukaan atau Mukadimah UUD, yaitu yang berbunyi Negara berdasarkan kepada Ketuhanan, dengan kewajiban menjalankan syari'at Islam 
bagi pemeluknya (H. Endang Saefudin Anshori, 1981:143). Tujuh kata terakhir ini kemudian oleh Panitia Persiapan Kemerdekaan Indonesia (PPM) tanggal 18 Agustus 1945 dihilangkan dan diganti dengan imbalan tambahan kata "Yang Maha Esa" dibelakang kata Ketuhanan, sehingga dalam Pembukaan tersebut berbunyi "Ketuhanan Yang Maha Esa".

Menurut Ismail Suny: sehubungan dengan Piagam Jakarta ini, bahwa dengan ketentuan 7 (tujuh) perkataan itu saja, sama sekali tidak berarti telah terbentuk negara Islam melalui Piagam Jakarta. Dengan kata lain itu dapat diartikan bahwa hukum Islam berlaku bagi pemeluk agama Islam sebagaimana halnya politik Hindia Belanda sebelum tahun 1929. Salah paham itu dapat diatasi kalau ada yang mengusulkan ketujuh kata itu menjadi berbunyi: "dengan kewajiban menjalankan ketentuan agama bagi pemeluknya'. Ini berarti pemeluk Islam wajib menjalankan hukum Islam, bagi pemeluk Katolik wajib menjalankan hukum Katolik, bagi pemeluk Kristen wajib menjalankan hukum Kristen, bagi pemeluk Hindu wajib menjalankan hukum Hindu bagi pemeluk Budha wajib menjalankan hukum Budha (Ismail Suny, 1988:6).

Selanjutnya dengan Proklamasi Kemerdekaan 17 Agustus 1945 dan berlakunya UUD 1945, walaupun tanpa tujuh kata dan Piagam Jakarta, teori resepsi yang landasan pijaknya adalah IS maka dengan telah berlakunya UUD 1945 dengan sendirinya teori resepsi menjadi gugur.

Setelah berlakunya UUD 1945, hukum Islam berlaku bagi Bangsa Indonesia yang beragama Islam, karena kedudukan hukum Islam itu sendiri selama 14 tahun, dan tanggal 22 Juni 1945 waktu ditanda tangani Gentlement Agriment antana pernimpinpemimpin Islam sampai 5 Juni 1959, sebelum Dekrit Presiden diundangkan, kedudukan kewajiban menjadi syari'at Islam bagi perneluknya adalah persuasive source, setelah Dekrit outorative suorce. (Ibid: 7).

Dengan dan atas dasar UUD negara Republik Indonesia ditetapkan politik hukum baru bagi negara Republik Indonesia. Buat dekade terakhir landasan operasionilnya dicantumkan dalam Garis-Garis Besar Haluan Negara (GBHN) yang berbunyi sebagai berikut:

Pembangunan di bidang hukum dalam negara hukum Indonesia adalah berdasarkan atas landasan sumber tertib hukum negara yaitu cita-cita hukum serta cita-cita moral yang luhur meliputi suasana kejiwaan serta, watak dan Bangsa Indonesia yang dipadatkan dalam Pancasila dan UUD 1945. Pembinaan di bidang hukum hanus mampu mengarahkan dan menampung kebutuhan-kebutuhan sesuai dengan kesadaran hukum rakyat yang berkembang ke arah modernisasi menurut tingkat kemajuan pembangunan di segala bidang sehmgga tercapai ketertiban dan kepastian hukum sebagai prasarana yang harus ditujukan ke arah peningkatan dan penyempurnaan pembinaan hukum nasional dengan antara lain mengadakan 
pembaharuan, kodifikasi serta unifikasi hukum di bidang-bidang tertentu. Dengan jalan memperhatikan kesadaran hukum dalam masyarakat.

Rumusan GBHN tahun 1973 itu diulang kembali dalam GBHN berikutnya yang terakhir dalam GBFIN tahun 1988 pun diulang kembali walaupun dengan kalimat yang agak berbeda, tetapi tetap dengan inti yang sama.

Persoalan sekarang adalah apakah kesadaran hukum masyarakat Indonesia Itu telah selaras, serasi dengan jiwa dan semangat hukum Islam? Apakah masyarakat Bangsa Indonesia --yang katanya mayoritas itu-- telah memiliki aspirasi, cita-cita dan pandangan hukum yang sesuai dan serasi dengan hukum Islam? Kalau tidak tentulah aspirasi cita-cita dan pandangan hukum lainlah yang akan terwujud dalam pembinaan hukum nasional nanti.

Suatu hal yang pasti adalah bahwa dalam masa mendatang akan selalu ada perubahan tata hukum Indonesia sebagai pengganti yang ada sekarang yang sudah tidak sesuai lagi dengan kebutuhan dan keadaan sekarang dan masa mendatang.

Para ahli sening mengatakan bahwa hukum yang baik ialah hukum yang serasi, selaras, dan sesuai dengan jiwa, aspirasi, cita-cita dan kesadaran hukum rakyat tersebut, hukum itu hendaknya bukan hukum yang asing bagi mereka, sebagaimana halnya dengan realitas sekarang ini.

Dalam pada itu perlu pula dikemukakan bahwa dalam rangka pembinaan hukum, pembaharuan hukum nasional dianut pemikiran seperti jelas tertuang dalam rumusan GBHN, tentang hukum akan ditempuh saluran perundang-undangan dan melalui penyerapan nilai-nilai yang hidup dalam masyarakat atau "kesadaran hukum masyarakat".

Oleh karena itu pengungkapan kesadaran hukum masyarakat itu dimungkinkan melalui penelitian hukum yang dilakukan oleh lembaga-lembaga penelitian, lembaga pendidikan, yurisprudensi, pendapat para ahli.

Dalam pada itu anggota masyarakat biasapun dapat pula memberikan sumbangannya, oleh karena pada akhirnya hukum itu adalah untuk mereka juga, tergantung kepada umat yang mayoritas ini di samping unsur-unsur lain yang mendukungnya.

Perlu dikemukakan di sini adalah diadakannya usaha-usaha yang sedang ditempuh oleh pemerintah, dalam hal ini Departemen Agama dengan dukungan Mahkamah Agung dalam kaitannya dengan hukum. Pada tanggal 21 Maret 1985 telah ditandatangani surat keputusan bersama, ketua Mahkamah Agung dan Menteri Agama tentang pelaksanaan proyek pembangunan hukum Islam melalui yurisprudensi. Usaha dan proyek ini adalah kompilasi hukum Islam di bidang hukum yang menjadi hukum materiil di Pengadilan Agama.

Hasil kompilasi hukum Islam itu nanti akan membantu meratakan jalan untuk tercapainya "Kodifikasi Hukum Islam di Indonesia". Harapan ini tidaklah berarti mengada-ngada, oleh karena pada dasarnya hukum Islam itu memiliki dinamika, kelincahan, dan vitalitas yang tinggi. Usaha tersebut telah berhasil dengan kehadiran Kompinasi Hukum Islam (KHI) melalui Istrumen Hukum, yaitu Instruksi Presiden 
(Inpres) No. 1 tahun 1991 tanggal 10 Juni 1991, dan antisipasi secara organik oleh Keputusan Menteri Agama No. 154 tahun 1991 tanggal 22 Juli 1991.

Di sinilah terletak tantangan bagi hakim agama dan ahli hukum Islam dituntut untuk maju dan mampu menjabarkan hukum Islam yang universal dan abadi itu dalam konteks alam Indonesia pada tingkat kemajuan pada abad XXI.

Dengan sedikit data-data yang telah kami sebutkan di atas, dapatlah disimpulkan bahwa hukum Islam di masa mendatang akan mengalami kecerahan, seiring dengan itu apabila dibaris kanan berdiri para umaro, dan di bans kin berdiri para ulama, dan dibelakangnya berdiri berjuta-juta kaum muslimin, Insya Allah rintihan doa kami dan orang-orang tua kami terdahulu akan segera terwujud.

\section{E. KESIMPULAN}

Dari uraian terdahulu bahwa pikiran-pikiran yang mendasarkan diri atas teori resepsi yang menempatkan hukum Islam sebagai penumpang terhadap hukum adat haruslah ditinggalkan sama sekali. Hal itu didasarkan bahwa pasal 134 IS sebagai hukum dasar ketatanegaraan Hindia Belanda yang sudah diganti/dibatalkan oleh UUD 1945.Dalam pembinaan dan pembentukan hukum internasional nanti kiranya hukum Islam mempunyai andil yang tidak kecil, hal ini disebabkan mayoritas Bangsa Indonesia adalah beragama Islam. 


\section{F. DAFTAR PUSTAKA}

Ali, Muhamad Daud. 1983. Kedudukan Hukum dalam Sistem Hukum Indonesia. Jakarta: Yayasan Risalah.

Anshori, Endang Saefudin. 1981. Piagam Jakarta 22 Juli 1945. Bandung: Pustaka.

Hashbi, Ashidqi. 1975. Pengantar Ilmu Perbandingan Mazhab. Jakarta: Bulan Bintang. Hanafi, Ahmad. 1984. Pengantar dan Sejarah Hukum Islam. Jakarta: Bulan Bintang.

Haryono, Anwar. 1970. Hukum Islam Keluasan dan Keadilannya. Jakarta: Bulan Bintang.

Hazairin. 1964. Hukum Kekeluargaan Nasional. Jakarta: Tinta Mas.

Lev. Daniel S. 1986. Islamic Cuort In Indonesia, atau Peradilan Agama Islam di Indonesia, ter. H. Zaini Ahmad Noeh. Jakarta: Intermasa.

Martokusumo, Sudikno. 1981. Bunga Rampai Hukum. Jogyakarta: Liberty.

Suny, Ismail. 1981. Mencari Keadilan. Jakarta: Ghalia Indonesia.

10 Oktober 1988. "Perkembangan Hukum islam di Indonesia" Makalah kuliah perdana untuk Ikatan Hakim Agama di Universitas Asyifi'ah, Jakarta.

Suroyo, Wigyodipuro. 1973. Pengantar dan Asas-Asas Hukum Adat. Bandung: Alumni.

Supomo. 1952. Sistem Hukum di Indonesia. Jakarta: Pradya Paramita. 